\title{
Levels and predictors of happiness in the south of the Islamic Republic of Iran
}

Ali Akbar Haghdoost, ${ }^{1}$ Mohsen Momeni, ${ }^{2}$ Faezeh Bahraminejad ${ }^{3}$ and Mina Danaei ${ }^{4}$

${ }^{1}$ HIV/STI Surveillance Research Center and WHO Collaborating Center for HIV Surveillance, Institute for Future studies in Health, Kerman University of Medical Sciences, Kerman, Islamic Republic of Iran. ${ }^{2}$ Modeling in Health Research Center, Institute for Future studies in Health, Kerman University of Medical Sciences, Kerman, Islamic Republic of Iran. ${ }^{3}$ Health Services Management Research Centre, Institute for Future studies in Health, Kerman University of Medical Sciences, Kerman, Islamic Republic of Iran. ${ }^{4}$ Social Determinants of Health Research Centre, Institute for Futures Studies in Health, Kerman University of Medical Sciences, Kerman, Islamic Republic of Iran (Correspondence to: Mina Danaei: danaei.mina@gmail.com).

\begin{abstract}
Background: Happiness is considered an index of the development of human society and well-being in the world.

Aims: The aim of this study was to measure the level of happiness in a middle sized Iranian city (Kerman) using 2 instruments and the predictor factors.

Methods: In a cross-sectional study, 1000 adults were questioned using multi-stage cluster sampling in 2016 . The LoH was assessed using the Oxford Happiness Inventory (OHI) and a self-report questionnaire. The level of physical activity and the religion index were assessed using standard questionnaires.

Results: The results of 2 questionnaires had a statistically significant correlation with measuring level of happiness (Pearson correlation coefficient 0.69; P-value < 0.001). Around 90\% of participants stated that they had moderate to high LoH, but the mean happiness score based on the OHI was 43.2 (43.7 in men, 42.7 in women). Illiteracy, unemployment, divorce, living in deprived areas, high level of stress, weak religious beliefs and practice, lower income, and poor health significantly decreased the LoH score.

Conclusion: Level of happiness is relatively low in Kerman. There are effective evidence-based interventions that might promote the LoH of the population, including promoting the level of community health, educating for stress management and improving access to urban facilities in deprived areas.

Keywords: happiness; mental health; risk factor; subjective well-being; oxford happiness

Citation: Haghdoost AA; Momeni M, Bahraminejad F; Danaei M. Levels and predictors of happiness in the south of the Islamic Republic of Iran. East Mediterr Health J. 2020;26(7):779-786. https://doi.org/10.26719/emhj.20.002

Received: 12/01/18; accepted: 02/12/18

Copyright ( $)$ World Health Organization (WHO) 2020. Open Access. Some rights reserved. This work is available under the CC BY-NC-SA 3.0 IGO license (https://creativecommons.org/licenses/by-nc-sa/3.o/igo)
\end{abstract}

\section{Introduction}

Today, mental health is an essential component of health and an increase in the level of happiness $(\mathrm{LoH})$ is one of the most important strategies for improving mental health $(1,2)$. Happiness is equal to subjective well-being and is described as a positive feeling composed of 3 main elements: a feeling of pleasure, satisfaction with life, and absence of negative feelings such as depression and anxiety (3). Taking into account its importance, happiness is considered an index of the development of human society and well-being (4). Previous studies have shown that the frequency of depression, anxiety, drug addiction, suicide, and cardiovascular disease is higher in people with insufficient LoH and life satisfaction, and this group experiences higher mortality rates $(5,6)$.

According to the available literature, many factors affect happiness $(7,8)$ :

- individual, e.g. genetics, age, sex, education, marital, employment, health status;

- psychological, e.g. life satisfaction, stress, personality, self-esteem;

- behavioural, e.g. addiction, alcohol use, tobacco use, physical activity, diet, sleep;
- social, e.g. social norms and values, social support, social engagement, community safety;

- environmental, e.g. urban fabric, natural disasters, weather;

- workplace, e.g. access to water and food, nature, lighting, ergonomic.

An international study in 2017 showed that happiness is a genetic-based sense and the influence of genetic factors and climate on the LoH is stronger than the economic and social situations (9).

International reports have indicated that different countries have different LoH. Based on 2017 statistics, the highest and lowest happiness scores were for Norway (score 7.53) and the Central African Republic (score 2.69). The happiness score of the Islamic Republic of Iran was 4.69, ranking it 108th among 155 countries that were studied (10). The international study asked the people to estimate their $\mathrm{LOH}$ on a 4-point Likert scale as "very happy", "rather happy", "not very happy" and "not at all happy". The mean percentages of "very happy" answers in 2000-2014 varied between $7.6 \%$ in Moldova to $60.8 \%$ in Mexico. Approximately $20 \%$ of the Iranian population estimated their LOH as "very happy" (9). Also, a national 
study revealed that the country in general, and the city of Kerman in particular, do not have satisfactory LoH (11), indicating that the LoH situation in the Islamic Republic of Iran is not promising.

Several studies have measured the LoH and its determinant factors by the Oxford Happiness Inventory (OHI) among different population groups in the Islamic Republic of Iran.A2018 study among an elderly population estimated the mean LoH score at 41.17, and concluded that social support is one of the important predictors of happiness among elders (12). A 2015 population-based study among 30-50-year-olds in Tehran measured mean LoH at 47.26 (13). A 2013 study estimated mean LoH among married women in Shahroud at 45.11 (5).

We need to identify the vulnerable subgroups and the causes of low LoH. However, existing studies and scientific works examining this issue are limited in the Islamic Republic of Iran, especially in Kerman. This historical city is situated in the south-east of the country on the fringes of the Loot desert. It has experienced many conflicts and natural disasters throughout its history. In addition, Kerman has encountered a prolonged drought with potential impacts on social, economic and health status. Apart from these, due to its proximity to the border with Afghanistan, the province has faced the challenges of drug trafficking and addiction. This has caused many social problems, including an increased number of divorces.

The aim of this study was to determine the average level and predictor factors of happiness among adults in the city of Kerman.

\section{Methods}

This population-based, cross-sectional survey was carried out during September-December 2016 in Kerman. Kerman city, the capital of Kerman province, is the largest city in the south-east of Iran, with a population around 700000 .

All individuals aged 18 and above, residing in Kerman for at least the previous 5 years were eligible to enter the study. Considering the standard deviation of the $\mathrm{LoH}$ as 0.97 in the previous study in the Islamic Republic of Iran (11), the confidence interval as 0.95 and the degree of precision as 0.09 , sample size was calculated as 447 . According to the multistage sampling method, the design effect was considered as 2 and sample size was calculated as 894 . Allowing for a $10 \%$ withdrawal rate, sample size was calculated at 994. In the end, 1000 participants were selected to increase the power of the study.

A multi-stage cluster sampling method was used. The city of Kerman was divided into 4 regions based on municipality areas. In each region, 5 blocks were selected randomly using the random numbers table. Then a number of households (approximately 50) were selected in each block using a systematic sampling method. All adults in each household were selected until the sample was complete. Taking into consideration the male:female ratio in the reference population of
Kerman, an equal sample size was estimated for males and females. Trained interviewers selected the eligible population through a door-to-door process and face-toface interviews. Verbal informed consent was obtained from the participants. Just under $10 \%$ of those selected refused to participate; in these cases, the next household replaced the original selection.

Through valid questionnaires, we assessed LoH, levels of physical activity, and religious beliefs and practice. Three questionnaires were used:

- The OHI was used to assess LoH. The OHI includes 29 questions with 4-item answers with scores ranging from 0 to 3 . The minimum and maximum scores in this questionnaire ranged from zero to 87 . This questionnaire was developed in 1989 by Hills and Argyle (14). Reliability of the Farsi version of the OHI in Iranian society using Cronbach's alpha and test-retest was 0.92 and 0.73 , respectively (15).

- A short form of the International Physical Activity Questionnaire was used to assess level of physical activity. Physical activity in the previous 7 days was measured by this valid and reliable questionnaire. The reliability and validity of the Persian version of this questionnaire were assessed by Moghadam and et.al with Cronbach's alpha as 0.85 (16). This questionnaire contained 7 questions covering 4 different areas, including vigorous physical activity, moderate physical activity, walking, and sitting. Energy intensity of total activities in the last 7 days was estimated based on the metabolic equivalents (METs) unit. Then METs were categorized as weak $(<600$ MET-minutes/week), moderate (600-3000 MET-minutes/ week), and vigorous (> $3000 \mathrm{MET}$-minutes/week).

- The Duke University Religion Index (DUREL) was used to assess religious beliefs and practice. The DUREL has 3 dimensions: organizational religiosity (1 item), nonorganizational religiosity (1 item), and intrinsic religiosity (3 items). Organizational religiosity and nonorganizational religiosity used a 6-point Likert-type scale while the 3 intrinsic religiosity items are scored on a 5-point Likert-type scale. The minimum and maximum scores in this questionnaire ranged from 5 to 27. In the Iranian setting, Cronbach's alpha for the Farsi version of the DUREL was 0.921 (17).

We need to find a valid, simple, and applicable instrument for measuring LoH in Iranian society. Therefore, according to a national survey, researchers used 1 self-report question to measure LoH with a 5-point Likert-type scale ranging from very high to never (11). This question was: "Do you feel happy?"

Sociodemographic questions covered age, sex, level of education, income, employment, marital status, place of residence, drug addiction, and alcohol and tobacco use. Stress level and health status were self-assessed.

We applied simple and multivariate (backward method) linear regression analyses to assess the correlation between independent variables and LoH. 
Also, we used the Pearson correlation coefficient to assess the agreement between 2 instruments for measuring LoH. The level of significance was set at 0.05. This study was registered by the Ethical Committee of Kerman University of Medical Sciences (Ethical code: IR.KMU. REC.1394.497).

\section{Results}

The age range of our participants was $18-88$ years (mean 34.07; SD 12.56). About half the participants were men $(51.8 \%)$; the majority were married $(56.3 \%)$, employed (50.7\%), university educated (51.0\%), and earned less than US\$ 450 per month (56.2\%) (Table 1 ).

According to the OHI, the mean and (mean $\pm \mathrm{SD}$ ) of the happiness score was 43.24 [standard deviation (SD) 15.8] [(men: 43.71 (SD 15.8); women: 42.73; SD 15.8)]. According to the self-report question, $2.7 \%, 7.4 \%, 52.2 \%$, $27.2 \%$, and $10.5 \%$ of participants estimated their LoH as none, low, moderate, high, and very high, respectively.

Comparison of the $\mathrm{OHI}$ and self-report question results showed a significant correlation between the 2 instruments for determining LoH (Pearson coefficient: $0.69 ; P<0.001)$.

The adjusted linear regression model showed a significant positive correlation between happiness and religious beliefs and practice $(\beta=0.58)$. Also, married

\begin{tabular}{|c|c|c|}
\hline \multicolumn{3}{|c|}{$\begin{array}{l}\text { Table } 1 \text { Sociodemographic characteristics of the study } \\
\text { participants }(n=1000) \text {, Kerman, } 2016\end{array}$} \\
\hline Characteristics & No. & $\%$ \\
\hline \multicolumn{3}{|l|}{ Sex } \\
\hline Men & 518 & 51.8 \\
\hline Women & 482 & 48.2 \\
\hline \multicolumn{3}{|l|}{ Marital status } \\
\hline Married & 562 & 56.3 \\
\hline Single & 384 & 38.4 \\
\hline Divorced/widowed & 53 & $5 \cdot 3$ \\
\hline \multicolumn{3}{|l|}{ Level of education } \\
\hline Illiterate & 17 & 1.7 \\
\hline$<$ High school & 153 & $15 \cdot 3$ \\
\hline High school diploma & 319 & 32.0 \\
\hline University & 508 & 51.0 \\
\hline \multicolumn{3}{|l|}{ Employment status } \\
\hline Housewife & 173 & 17.3 \\
\hline Retired & 63 & 6.3 \\
\hline Employed & 506 & 50.7 \\
\hline Student & 190 & 19 \\
\hline Unemployed & 66 & 6.6 \\
\hline \multicolumn{3}{|l|}{ Income (US\$s per month) } \\
\hline$<150$ & 148 & 15 \\
\hline $150-450$ & 407 & 41.2 \\
\hline $450-750$ & 260 & 26.3 \\
\hline$>750$ & 172 & 17.4 \\
\hline
\end{tabular}

people had a significantly higher happiness score than divorced or widowed people $(\beta=4.10)$, and people living in deprived areas had a significantly lower score of happiness than others $(\beta=-2.95)$. People with a medium level of income had significantly lower $\mathrm{LOH}$ than people with a high level of income. $(\beta=-6.38)$ The highest level of health $(\beta=19.31)$, the lowest level of stress $(\beta=11.77)$, university education $(\beta=3.20)$ and being retired $(\beta=6.32)$ were significantly associated with high LoH. According to this model, health status and religion had the highest and lowest association with LoH, respectively and R2 was 0.30. Despite higher scores of happiness in men and in people who did not use alcohol or tobacco, sex $(P=0.155)$, alcohol use $(P=0.364)$, tobacco use $(P=0.072)$, and age $(P=0.058)$ were not statistically significantly associated with LoH (Table 2).

\section{Discussion}

\section{Level of happiness}

According to the OHI, the score of happiness was 43.24 (SD 15.8) [men: 43.71 (SD 15.8); women: 42.73 (SD 15.8)] in Kerman. Considering that 87 is the highest score of happiness, this score is not high enough comparing with other studies in the Islamic Republic of Iran. The happiness score in Kerman was similar to that of Tehran in 2007: 42.07 (SD 12.98) (18) and Tehran in 2015: 47.26 (SD 15.2) (13), but it was higher than in Bam in 2014: 32.7 (SD 11.02) (19). Bam had a poor score due to a disaster that its citizens experienced after the catastrophic 2003 earthquake. The score of happiness in our study was lower than in Esfahan in 2012 (66.5) (20).

From the one question, there was a notable difference between our results and the results of a national survey in 2009 (11), which found that the LoH was lower. According to an international study, approximately $20 \%$ of the Iranian population estimated their LoH as "very happy" (9), while only $10.5 \%$ estimated their LoH as "very happy" in our study.

\section{Predictor factors}

\section{Age and happiness}

The results of various studies are contradictory when it comes to examining the relationship between age and happiness. Some research has shown a significant and positive relationship (1) but other studies have shown opposite results $(11,21)$. Some studies suggest that the relationship between age and happiness is a U-form model. In this model, the highest LoH is for ages 20-29 years and after age 50 years $(22,23)$. Yet others have shown that there is no meaningful relationship $(24,25)$. Our study showed that there was no statistically significant association between age and LoH.

\section{Marital status and happiness}

In our study, married people had on average 4.10 [95\% confidence interval (CI) 0.15-8.05] higher LoH compared with divorced or widowed people but there was no significant difference between single and divorced or widowed 


\begin{tabular}{|c|c|c|c|c|c|c|c|}
\hline \multirow[t]{2}{*}{ Variable } & \multirow[t]{2}{*}{ Score of happiness } & \multirow[t]{2}{*}{ Diff } & \multicolumn{2}{|c|}{ Crude } & \multirow[t]{2}{*}{ Diff } & \multicolumn{2}{|c|}{ Adjusted } \\
\hline & & & P-value & $95 \% \mathrm{CI}$ & & P-value & $95 \%$ CI \\
\hline Age & - & 0.05 & 0.190 & $-0.03 ; 0.13$ & 0.09 & 0.058 & $-0.003 ; 0.19$ \\
\hline Religion & - & 0.72 & $<0.001$ & $0.51 ; 0.93$ & 0.58 & $<0.001$ & $0.38 ; 0.78$ \\
\hline \multicolumn{8}{|l|}{ Sex } \\
\hline Male & 43.71 & - & - & - & - & - & - \\
\hline Female & 42.73 & -0.98 & 0.327 & $-2.94 ; 0.98$ & - & - & - \\
\hline \multicolumn{8}{|l|}{ Level of education } \\
\hline Illiterate & 37.01 & - & - & - & - & - & - \\
\hline$<$ High school & 39.81 & 2.80 & 0.487 & $-5.09 ; 10.68$ & -0.46 & 0.895 & $-7.32 ; 6.40$ \\
\hline High school diploma & 42.56 & 5.55 & 0.156 & $-2.13 ; 13.23$ & 2.51 & 0.081 & $-3.11 ; 5.31$ \\
\hline University & 44.87 & 7.86 & 0.043 & $0.25 ; 15.47$ & 3.20 & 0.025 & $0.41 ; 5.98$ \\
\hline \multicolumn{8}{|l|}{ Employment status } \\
\hline Unemployed & 35.22 & - & - & - & - & - & - \\
\hline Housewife & & 5.04 & 0.026 & $0.60 ; 9.47$ & 4.36 & 0.039 & $0.21 ; 6.51$ \\
\hline Student & 43.77 & 8.55 & $<0.001$ & $4.17 ; 12.92$ & 5.32 & 0.009 & $1.34 ; 9.30$ \\
\hline Employed & 44.75 & 9.52 & $<0.001$ & $5.51 ; 13.53$ & 6.30 & 0.001 & $2.57 ; 10.03$ \\
\hline Retired & 46.14 & 10.92 & $<0.001$ & $5.52 ; 16.31$ & 6.32 & 0.021 & $0.94 ; 11.70$ \\
\hline \multicolumn{8}{|l|}{ Marital status } \\
\hline Divorced/ widowed & 35.88 & - & - & - & - & - & - \\
\hline Single & 43.12 & 7.24 & 0.002 & $2.72 ; 11.76$ & 4.07 & 0.066 & $-0.27 ; 8.41$ \\
\hline Married & 43.99 & 8.11 & $<0.001$ & $3.68 ; 12.55$ & 4.10 & 0.042 & $0.15 ; 8.05$ \\
\hline \multicolumn{8}{|l|}{ Living in a deprived area } \\
\hline No & 44.25 & - & - & - & - & - & - \\
\hline Yes & 38.97 & -5.28 & $<0.001$ & $-7.74 ;-2.28$ & -2.95 & 0.010 & $-5.19 ;-0.71$ \\
\hline \multicolumn{8}{|l|}{ Income (US\$ per month) } \\
\hline$>750$ & 49.66 & - & - & - & - & - & - \\
\hline $450-750$ & 44.19 & -5.47 & $<0.001$ & $-8.47 ;-2.47$ & -3.70 & 0.008 & $-6.41 ;-0.98$ \\
\hline $150-450$ & 41.14 & -8.52 & $<0.001$ & $-11.30 ;-5.47$ & -6.38 & $<0.001$ & $-8.96 ;-3.60$ \\
\hline$<150$ & 39.88 & -9.78 & $<0.001$ & $-13.20 ;-6.36$ & -3.13 & 0.064 & $-6.46 ; 0.18$ \\
\hline \multicolumn{8}{|l|}{ Health status } \\
\hline Weak & 26.11 & - & - & - & - & - & - \\
\hline Moderate & 34.94 & 8.83 & 0.002 & $3.29 ; 14.37$ & 4.80 & 0.081 & $-0.50 ; 10.19$ \\
\hline Good & 43.15 & 17.03 & $<0.001$ & $11.70 ; 22.37$ & 10.24 & $<0.001$ & $4.92 ; 15.56$ \\
\hline Excellent & 53.40 & 27.29 & $<0.001$ & $21.77 ; 32.80$ & 19.34 & $<0.001$ & $13.76 ; 24.85$ \\
\hline \multicolumn{8}{|l|}{ Chronic disease } \\
\hline Yes & 39.62 & - & - & - & - & - & - \\
\hline No & 43.65 & 4.02 & 0.018 & $7.35 ; 0.70$ & - & - & - \\
\hline \multicolumn{8}{|l|}{ Stress level } \\
\hline High & 34.98 & - & - & - & - & - & - \\
\hline Moderate & 39.38 & 4.40 & 0.010 & $1.04 ; 7.77$ & 3.14 & 0.049 & $0.04 ; 6.28$ \\
\hline Low & 45.79 & 10.81 & $<0.001$ & $7.57 ; 14.06$ & 6.21 & $<0.001$ & $3.08 ; 9.34$ \\
\hline No & 53.83 & 18.85 & $<0.001$ & $14.51 ; 23.19$ & 11.77 & $<0.001$ & $7.63 ; 15.89$ \\
\hline \multicolumn{8}{|l|}{ Living situation } \\
\hline Alone & 37.99 & - & - & - & - & - & - \\
\hline With friends & 41.10 & 3.11 & 0.388 & $-3.96 ; 10.18$ & - & - & - \\
\hline With family & 43.56 & 5.57 & 0.010 & $1.32 ; 9.83$ & - & - & - \\
\hline \multicolumn{8}{|l|}{ Physical activity } \\
\hline Low & 40.18 & - & - & - & - & - & - \\
\hline Moderate & 43.26 & 3.07 & 0.038 & $0.17 ; 5.97$ & - & - & - \\
\hline High & 44.56 & 4.38 & $<0.001$ & $1.98 ; 6.77$ & - & - & - \\
\hline
\end{tabular}




\begin{tabular}{|c|c|c|c|c|c|c|c|}
\hline \multirow[t]{2}{*}{ Variable } & \multirow[t]{2}{*}{ Score of happiness } & \multirow[t]{2}{*}{ Diff } & \multicolumn{2}{|c|}{ Crude } & \multirow[t]{2}{*}{ Diff } & \multicolumn{2}{|c|}{ Adjusted } \\
\hline & & & P-value & $95 \% \mathrm{CI}$ & & P-value & $95 \% \mathrm{CI}$ \\
\hline \multicolumn{8}{|c|}{ Alcohol use } \\
\hline Yes & 43.11 & - & - & - & - & - & - \\
\hline No & 43.28 & 0.16 & 0.915 & $-3.13 ; 2.81$ & - & - & - \\
\hline \multicolumn{8}{|c|}{ Tobacco use } \\
\hline Yes & 42.21 & - & - & - & - & - & - \\
\hline No & 43.53 & 1.32 & 0.275 & $-1.05 ; 3.69$ & - & - & - \\
\hline \multicolumn{8}{|l|}{ Addiction } \\
\hline Yes & 38.07 & - & - & - & - & - & - \\
\hline No & 43.58 & 5.51 & 0.007 & $1.48 ; 9.55$ & - & - & - \\
\hline
\end{tabular}

Dif = difference; $C I=$ confidence interval.

people. Although the results of a national survey in Iran showed that single people had higher happiness than married people (11), most studies revealed that marriage is associated with a higher happiness level and divorced and widowed people had the lowest the score of happiness $(24,26)$. In a national cohort of Thai adults, married people had a higher LoH than single people and single people had a higher LoH than divorced or widowed people (26). The effect of marital status on happiness was minimal among older women and maximal among younger men. The reason for this is that married people have healthier lifestyles and better health status than single people. Also, married people have better support systems than others, especially divorced and widowed people.

\section{Employment status and happiness}

Our research revealed that unemployment was a significant factor associated with low LoH. The retired and employed people had 6.32 and 6.30 higher LoH respectively than unemployed people. The results of a national survey showed that unemployed people had the lowest LoH in the Islamic Republic of Iran (11). Many studies have shown that unemployment can reduce happiness (26-28). Unemployment can lead to unhappiness through poverty, crime, mental illness, feelings of worthlessness and bad decision-making.

\section{Income and happiness}

One of the most important factors affecting happiness is income deprivation $(11,24,25,29)$. Our data also revealed that a middle level of income has an association with unhappiness. It seems that people with middle levels of income are always worried about poverty. They also compare themselves to rich people and try to increase their levels of income. This leads to increased anxiety and unhappiness in this group.

\section{Health status and happiness}

Our findings indicated a strong positive relationship between health and happiness. People with an excellent health status had on average 19.34 (95\% CI 13.76-24.85) higher LoH compared with those with poor health status. Several other studies have shown that health status is one of the most important factors affecting happiness
$(11,24,30)$. People with low levels of health are unable to achieve their goals. Thus, their LoH goes down.

\section{Stress and happiness}

In this study, there was a significant inverse relationship between stress and happiness. Individuals who did not have stress had an 11.77 (95\% CI 7.63-15.89) higher LoH than individuals with a high level of stress. Based on results of other studies, not only does increase in stress levels reduce feelings of happiness significantly, but the frequency of depression, anxiety, drug addiction and suicide are also higher in people with insufficient LoH and life satisfaction; this group is also likely to have higher mortality rates $(5,8)$. High levels of stress lead to a lack of compliance with new conditions and thus, reduce LoH. Stress is also a major risk factor for communicable and noncommunicable diseases and can lead to reduced LoH through disease.

\section{Living in deprived areas and happiness}

This study found that living in deprived areas is an important factor in low happiness. A number of studies have shown that people living in deprived areas experience less happiness $(31,32)$. Social deprivation, poor health status and lack of access to urban facilities in deprived areas have led to low LoH in people living in these areas.

\section{Religion and happiness}

This study found a significant positive correlation between religious attitude and behaviour and happiness. A unit increase in the religion score led to an increase of 0.58 in the happiness score. Previous research conducted in Muslim societies corroborates this relationship (33), but the results of another Iranian study revealed that dogmatism, especially religious dogmatism, had negative effects on LoH (13). Religious beliefs lead to spiritual relaxation and increased happiness. Also, organized religious practices lead to an increase in happiness through an increase in social engagement.

\section{Sex and happiness}

There was no significant association between sex and LoH. Other studies have shown inconsistent results. In most studies happiness was higher in men than in women $(11,21)$. In some studies, there was no significant relation- 
ship between LoH and sex $(1,25)$, or LoH was higher in women (24). However, results can differ in the Islamic Republic of Iran. A national survey indicated that men were happier than women (11) but studies in Esfahan and Ilam showed that the score of happiness was higher in women although the difference was not statistically significant $(1,20)$. It seems that other social factors may be involved, including women's participation in the community.

\section{Level of education and happiness}

People with university education had on average a 3.20 (95\% CI 0.41 to 5.98) higher LoH compared with illiterate people in the present study. Results of most studies demonstrated that people with high education levels have higher LoH (24). However, in a national Iranian survey and in other studies, there was no significant association between education and happiness. $(1,11,25)$. People with a high level of education have a high level of self-confidence and self-esteem, which may lead to a high LOH.

\section{Lifestyle and happiness}

Most studies showed that an unhealthy lifestyle is a risk factor for low LoH $(7,21,30,34,35)$. Although in our study LoH was lower in participants with an unhealthy lifestyle (such as tobacco, alcohol and drug use) and low levels of physical activity, there was no statistically significant relationship between LoH and unhealthy lifestyle according to the adjusted regression model. Perhaps lifestyle has an indirect effect on LoH by impacting health.

To the best of our knowledge, no study has been conducted on LoH and associated factors based on a large sample size of adults in the south of the Islamic Republic of Iran. Due to the cross-sectional nature of this study, we cannot examine causal relationships. Because of bias related to social desirability, it is possible that the frequency of some behaviours, including alcohol consumption, was underestimated. Considering the $R^{2}$ of the final model, the goodness of fit in this linear regression model was poor. The authors suggest that future studies should be conducted to examine the relationship between happiness and factors such as social capital and urban fabric.

\section{Conclusions}

Our findings showed that LoH is relatively low in Kerman. Considering the relationship between several sociodemographic factors and the LoH, policy-makers should design targeted interventions in Kerman on vulnerable subgroups, such as those who are illiterate, unemployed, divorced and living in deprived areas and those who have low income, poor health, high levels of stress and weak religious beliefs.

Due to the increasing marginalization in Kerman, policy-makers should pay more attention to these deprived areas and provide better welfare facilities.

\section{Acknowledgment}

This research was conducted by Faezeh Bahraminejad in partial fulfilment of the requirements for the degree of Doctor of Medicine at Kerman University of Medical Sciences.

Funding: The Vice-Chancellor for research at Kerman University of Medical Sciences funded this research project (Grant number: 94/482).

Competing interests: None declared.

\section{Niveau et facteurs prédictifs de bonheur dans le sud de la République islamique d'Iran Résumé}

Contexte : Le bonheur est considéré comme un indice de développement de la société humaine et du bien-être dans le monde.

Objectifs : La présente étude avait pour objectif de mesurer le niveau de bonheur dans une ville iranienne de taille moyenne (Kerman) au moyen de deux instruments et de facteurs prédictifs.

Méthodes : Dans une étude transversale, 1000 adultes ont été interrogés en 2016 dans le cadre d'un échantillonnage en grappes à plusieurs degrés. Le niveau de bonheur a été évalué à l'aide de l'Oxford Happiness Inventory (OHI) et d'un questionnaire d'auto-évaluation. Le niveau d'activité physique et l'indice de religiosité ont été évalués à l'aide de questionnaires types.

Résultats : Les résultats des deux questionnaires étaient corrélés de manière statistiquement significative avec la mesure du niveau de bonheur (coefficient de corrélation de Pearson : 0,69; valeur $p<0,001$ ). Près de 90\% des participants ont déclaré être modérément ou tout à fait heureux, mais le score de bonheur moyen selon l'OHI était de 43,2 (43,7 chez les hommes, 42,7 chez les femmes). L'analphabétisme, le chômage, le divorce, le fait de vivre dans des zones défavorisées, le niveau élevé de stress, les croyances et les pratiques religieuses faibles, les revenus peu élevés et un mauvais état de santé faisaient nettement baisser le niveau de bonheur.

Conclusion : Le niveau de bonheur est relativement faible à Kerman. Il existe des interventions efficaces, fondées sur des bases factuelles, qui pourraient améliorer le niveau de bonheur de la population, y compris la promotion du niveau de santé communautaire, l'éducation à la gestion du stress et l'amélioration de l'accès aux infrastructures urbaines dans les zones défavorisées. 


$$
\begin{aligned}
& \text { مستويات ومؤشر ات السعادة في جنوب جمهورية إيران الإسلامية } \\
& \text { علي اكبر حق دوست، محسن مؤمني، فائزة بهر امي نجاد، مينا دانانى } \\
& \text { الخالاصة } \\
& \text { الخلفية: تُعتبر السعادة، في جميع أنحاء العالم، مؤشراً على تطور المجتمع البشري وعافية سكانه. } \\
& \text { الأهداف: هدفت هذه الدراسة إلى قياس مستوى السعادة في مدينة كرمان الإيرانية المتوسطة الحجم، باستخدام أداتين والعو امل المُنبِّة. }
\end{aligned}
$$

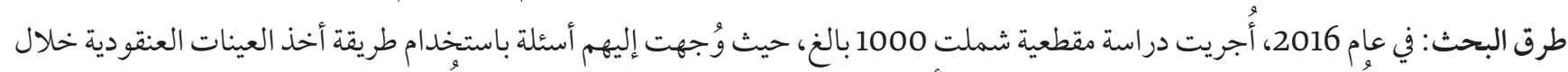

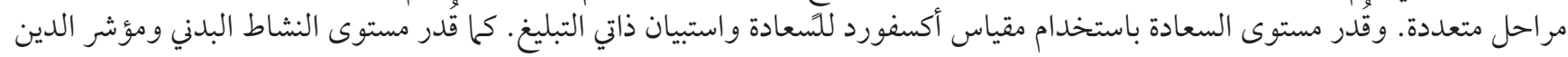

$$
\begin{aligned}
& \text { باستخدام استبيانات معيارية. } \\
& \text { النتائج: أوضحت نتائج استيانين وجود تر ابط ذي دلالة إحصائية في قياس مستوى السعادة (معامل ارتباط بيرسون: 0.69؛ و القيمة الاحتهالية }
\end{aligned}
$$

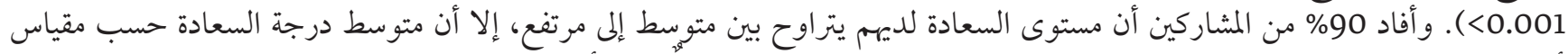

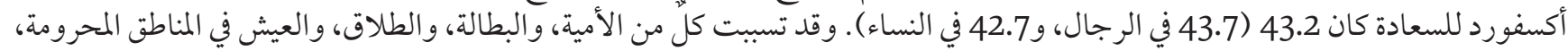

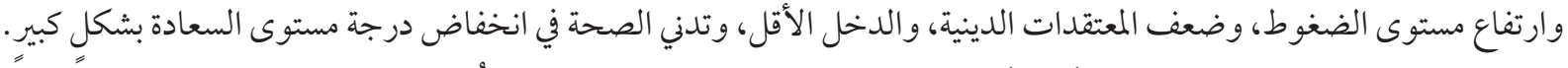

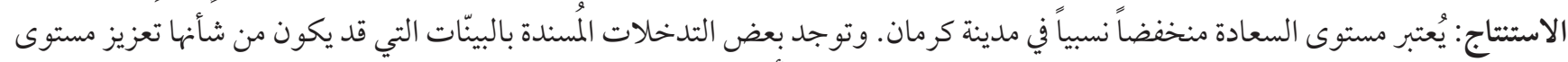

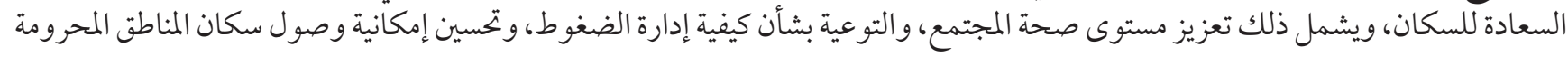

$$
\begin{aligned}
& \text { إلى المرافق الحضرية. }
\end{aligned}
$$

\section{References}

1. Mehrdadi A, Sadeghian S, Direkvand-Moghadam A, Hashemian A. Factors Affecting Happiness: A Cross-Sectional Study in the Iranian Youth. Journal of clinical and diagnostic research : JCDR. 2016 May;10(5):Vco1-vc3. PMID:27437333.

2. Promoting mental health: Concepts, emerging evidence, practice: Summary report. Geneva: World Health Organization; 2004.

3. Diener E. Assessing well-being: the collected works of Ed Diener: Springer Science \& Business Media; 2009.

4. United Nations General Assembly; Sixty-seventh session. Happiness: towards a holistic approach to development. Note by the Secretary-General. New York: United Nations; 2013 (A/67/697).

5. Sooky Z, Keramat A, Sharifi K, Dehghani M, Tagharrobi Z, Taebi M, et al. Investigating happiness and its related factors in married women referred to health centers of shahroud city. Iranian Red Crescent Med J. 2014 Sep;16(9):e22211. PMID:25593738.

6. Steptoe A, Wardle J, Marmot M. Positive affect and health-related neuroendocrine, cardiovascular, and inflammatory processes. Proc Natl Acad Sci USA. 2005;102(18):6508-12. doi:10.1073/pnas.0409174102

7. Piqueras JA, Kuhne W, Vera-Villarroel P, van Straten A, Cuijpers P. Happiness and health behaviours in Chilean college students: a cross-sectional survey. BMC Public Health. 2011 Jun 07;11:443. PMID:21649907

8. Schiffrin HH, Nelson SK. Stressed and happy? Investigating the relationship between happiness and perceived stress. J happiness studies. 2010;11(1):33-9.

9. Minkov M, Bond MH. A genetic component to national differences in happiness. J Happiness Studies. 2017;18(2):321-40.

10. Helliwell JF, Huang H, Wang S. The social foundations of world happiness. In: Helliwell J, Layard R, Sachs J, eds. World happiness report 2017. New York: United Nations; 2017 (Ch 2:8-47).

11. Montazeri A, Omidvari S, Azin A, Aeenparast A, Jahangiri K, Sadighi J, et al. [Happiness among Iranian population: findings from the Iranian Health Perception Survey (IHPS)]. Payesh. 2012;11(4):467-75 (in Farsi).

12. Moeini B, Barati M, Farhadian M, Ara MH. The association between social support and happiness among elderly in Iran. Korean J Fam Med. 2018 Jul;39(4):260-265. doi:10.4082/kjfm.17.0121

13. Malmir M, Khanahmadi M, Farhud D. Dogmatism and happiness. Iran J Public Health. 2017;46(3):326. PMID:28435818

14. Hills P, Argyle M. The Oxford Happiness Questionnaire: a compact scale for the measurement of psychological well-being. Personality Individual Differences. 2002;33(7):1073-82.

15. Liaghatdar MJ, Jafari E, Abedi MR, Samiee F. Reliability and validity of the Oxford Happiness Inventory among university students in Iran. Spanish J Psychol. 2008;11(1):310. doi:10.1017/S1138741600004340

16. Moghadam M, Hajikazemi E, RoozberM F, Hosseini AF. Relationship between physical activity and triceps skin fold thickness in adolescent girl students. Iran Nursing. 2011;24(69):62-8.

17. Saffari M, Zeidi IM, Pakpour AH, Koenig HG. Psychometric properties of the Persian version of the Duke University Religion Index (DUREL): a study on Muslims. J Religion Health. 2013;52(2):631-41. 
18. Alipour A, Agah Heris M. Reliability and validity of the Oxford Happiness Inventory among Iranians. J Iran Psychologists. 2007;3(12):287-98.

19. Afshinmehr H, Weisi F, Mortazavi SS, Zinat-Motlagh FL, Mahboubi M. Relationship between Islamic copying styles and happiness state in parents of exceptional children. J Sci Today's World. 2014;567-70.

20. Kiani M. Happiness and social capital in Iranian families. World Applied Sci J. 2012;18(8):1030-6.

21. Richards J, Jiang X, Kelly P, Chau J, Bauman A, Ding D. Don't worry, be happy: cross-sectional associations between physical activity and happiness in 15 European countries. BMC Public Health. 2015 Jan 31;15:53. PMID:25636787

22. Garaigordobil M. Predictor variables of happiness and its connection with risk and protective factors for health. Front Psychol. 2015 Aug 12;6:1176. doi:10.3389/fpsyg.2015.01176

23. Frijters $\mathrm{P}$, Beatton $\mathrm{T}$. The mystery of the U-shaped relationship between happiness and age. J Economic Behavior \& Organization. 2012;82(2):525-42.

24. Subramanian SV, Kim D, Kawachi I. Covariation in the socioeconomic determinants of self rated health and happiness: a multivariate multilevel analysis of individuals and communities in the USA. J Epidemiol Community Health. 2005 Aug;59(8):664-9. PMID:16020643

25. Ergin I, Mandiracioglu A. Demographic and socioeconomic inequalities for self-rated health and happiness in elderly: the situation for Turkey regarding World Values Survey between 1990 and 2013. Arch Gerontol Geriatrics. 2015 Sep-Oct;61(2):224-30. PMID:26153553

26. Yiengprugsawan V, Somboonsook B, Seubsman SA, Sleigh AC. Happiness, mental health, and socio-demographic associations among a national cohort of Thai adults. J Happiness Studies. 2012 Dec;13(6):1019-29. PMID:23304071

27. Winkelmann R. Unemployment and happiness. IZA World of Labor; 2014 (https://wol.iza.org/uploads/articles/94/pdfs/unemployment-and-happiness.pdf, accessed 21 December 2019).

28. Sharif MY, Majid AHA. A conceptual framework of happiness at the workplace. Asian Social Sci. 2014;11(2):78.

29. Chan $\mathrm{CH}$, Wong HK, Yip PS. Associations of relative income deprivation with perceived happiness and self-rated health among the Hong Kong Chinese population. Int J Public Health. 2017;62(6):697-707. PMID:28293717

30. Yiengprugsawan V, Seubsman SA, Sleigh AC. Unhappiness and mortality: evidence from a middle-income Southeast Asian setting. Biopsychosoc Med. 2014 Aug 7;8:18. doi:10.1186/1751-0759-8-18

31. Cramm JM, Møller V, Nieboer AP. Individual-and neighbourhood-level indicators of subjective well-being in a small and poor Eastern Cape township: The effect of health, social capital, marital status, and income. Soc Indic Res. 2012;105(3):581-93. doi:10.1007/s11205-011-9790-0

32. Bond L, Kearns A, Mason P, Tannahill C, Egan M, Whitely E. Exploring the relationships between housing, neighbourhoods and mental wellbeing for residents of deprived areas. BMC Public Health. 2012 Jan 18;12:48. doi:10.1186/1471-2458-12-48

33. Sahraian A, Gholami A, Javadpour A, Omidvar B. Association between religiosity and happiness among a group of Muslim undergraduate students. J Relig Health. 2013 Jun;52(2):450-3. doi:10.1007/s10943-011-9484-6

34. Wen M, Kye SY, Kwon JH. Happiness and health behaviors in South Korean adolescents: a cross-sectional study. JMIR Public Health Surveill. 2016;38:e2016022. PMID:27283139

35. Fararouei M, Brown IJ, Akbartabar Toori M, Estakhrian Haghighi R, Jafari J. Happiness and health behaviour in Iranian adolescent girls. J Adolesc. 2013 Dec;36(6):1187-92. doi:10.1016/j.adolescence.2013.09.006 